\title{
A talajban előforduló régészeti anyagok mikromorfológiai vizsgálata
}

\section{A régészeti mikromorfológia kialakulása}

A vékonycsiszolatok alkalmazása a talajtani kutatásokban már az 1930-as években megkezdődött. KUBIENA (1938) nevéhez füződik a bolygatatlan talajok/üledékek vékonycsiszolat formájában történő vizsgálata elsőként, legalábbis ami a publikált munkákat illeti. Mintegy 20 évvel később CORNWALL (1958) alkalmazza ezt a technikát elsőként régészeti összefüggésben, amikor is a múltban lezajlott környezeti változásokkal kapcsolatos kérdésekre keres választ, természetesen az emberi behatásokat, ill. beavatkozásokat is figyelembe véve.

A vékonycsiszolatok talajtani alkalmazása rengeteg problémával járt. A technikai problémákon túl, melyek a nagy méretủ minták impregnálása során léptek fel, a csiszolatok leírása is problematikus volt. Az utóbbi problémát megoldandó, BREWER (1964) kidolgozott egy leíró rendszert, amit széles körben használtak. Ezután egy újabb közel húsz éves ür következik, ugyanis egészen 1985-ig kell várni, hogy megjelenjen BULLOCK és munkatársai (1985) szerkesztésében az a kézikönyv, amely még napjainkban is a vékonycsiszolatok leírásának alapjául szolgál. Ez az első olyan mü, amelynek segítségével a régészeti talajokban/rétegekben lezajló folyamatok megértése lehetővé válik. A kézikönyv föként a természetes folyamatok, illetve a természetes talajokban megfigyelhető komponensek leírását tartalmazza. Mivel azonban ezek a folyamatok ugyanúgy befolyásolják a régészeti lelőhelyek anyagát, mint a természetes talajokat, illetve mivel a régészeti „talajokat” felépítő komponensek jelentős része a természetben megtalálható komponensek közül kerül ki, így kiválóan alkalmas a régészeti talajok/rétegek leírására is.

Itt egy gondolat erejéig mindenképp ki kell térnünk a természetes talajok, illetve a régészeti rétegek közötti különbségekre, hisz a régészek által kutatott „,talajokat” az esetek túlnyomó részében célszerübb a réteg, illetve rétegződés szóval jellemezni. Az angolszász nyelvterületen használt ,,anthropogenic sediment” kifejezés, amely az emberi tevékenység következtében felhalmozódott anyagra utal igen kifejező, így az antropogén réteg vagy rétegződés kifejezés használata tűnik a legkézenfekvőbbnek. A „sediment” szó eredeti jelentése üledék, azonban az üledék szó magyar terminológiában való alkalmazása nem szerencsés. Mivel a régészek a leleteket magukba záró közeget a réteg, illetve rétegződés szóval jellemzik, célszerünek tűnik az általuk használt kifejezéssel élni a félreértések elkerülése érdekében. Mivel a régészeti mikromorfológia kifejezetten a régészeti rétegek vizsgálatára specializálódott módszer, a már gyakorlatban lévő terminusok használata javasolt.

A talajok kialakulása természetes folyamatok sorához kötött (amit az ember természetesen befolyásolni, illetve átalakítani képes). Ezzel ellentétben az antropogén rétegek 
nem csupán a természetből kikerült komponenseket tartalmaznak, hanem egyéb kizárólag emberi tevekénységhez köthető anyagokat is (pl. használati és ruházati tárgyak, építő anyagok, ékszerek stb.). Természetesen ezeknek a részeknek a leírása is nélkülözhetetlen ezért további definíciók szükségesek a kizárólag régészeti összefüggésben előforduló komponensekkel kapcsolatban. Ezen definíciók egy része a kutatással együtt alakult ki, mint például a kérődző állatok ürülékében képződő szferolitok (1. ábra), amelyeknek fitolitokkal (2. ábra) együtt történő megjelenése egyértelműen a trágya jellemzője (CANTI, 1997, 1998, 1999).

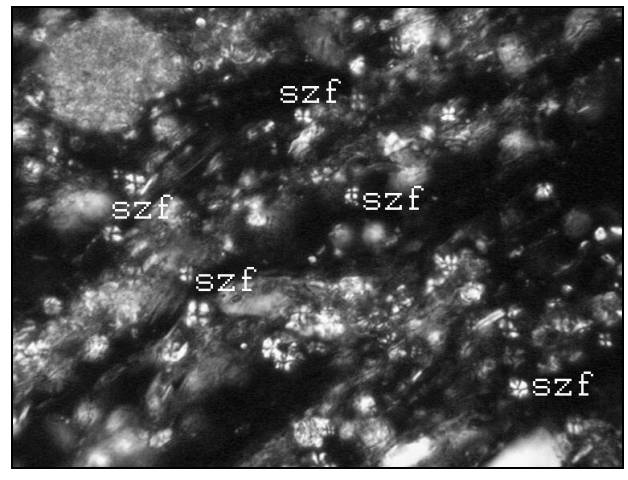

1. ábra

Szferolitok (szf) (Nagyítás 250×)

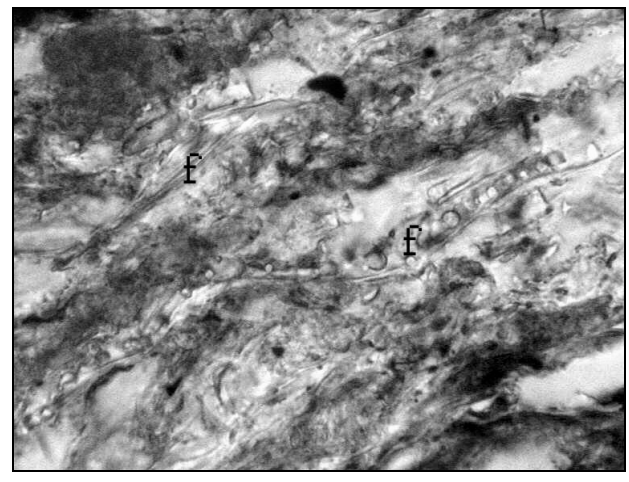

2. ábra

Filtolitok (f) (Nagyítás 250×)

A fitolitok [növényi sejtfal megerősítését szolgáló kovakristályok, melyeket nagyobb mennyiségben a pázsitfüfélék (Graminae) családjába tartozó növények tartalmaznak (PIPERNO, 1988)] ugyan jelen lehetnek a természetes talajokban is, a régészeti rétegekben való megjelenésük azonban sokkal nagyobb jelentőségü. Ezek a mikroszkopikus mérettartományba eső kristályok a növény szerves részeinek lebomlása után is megmaradnak, és jellegzetes formájuknak köszönhetően meghatározott fajtához köthetőek. A fitolitok segítségével a korabeli állattartással, növénytermesztéssel, illetve a vegetációval kapcsolatban nyerhetünk értékes információkat.

Az állattartással kapcsolatos információink túlnyomó része a csontok vizsgálatából származik, melyhez további bizonyítékkal szolgálhatnak a fitolitok. Segítségükkel meghatározhatjuk az állattartás módját (pl. legeltetéses, istállózó) (BOSCHIAN \& MONTAGNARI-KOKELJ, 2000; SHAHACK-GROSS et al., 2003), az állatok takarmányozási szokásait, ezáltal közvetve az elérhető erőforrásokat és bizonyos esetekben adatokat nyerhetünk a környezettel kapcsolatban is.

A növénytermesztéssel kapcsolatban a szenült növényi maradványok vizsgálatán keresztül informálódhatunk (K-BERZSÉNYI \& KOVÁCS, 2004). Az ilyen jellegü maradványok feltárása vízből történő kiülepítéssel, illetve lebegtetéssel (egyszóval flotálással) történik (lásd pl. VICZE, 2005). A folyamatban használt sziták mérettartománya nem alkalmas a mikroszkopikus méretü részek felfogására, így a fitolitok kinyerésére sem. Ezért a vékonycsiszolat-analízissel kiegészített növénytani és csonttani vizsgálatok olyan adatokkal szolgálhatnak, melyeket önmagában egyik tudományág sem képes feltárni. 
Említést érdemel még STOOPS (2003) könyve, amely a BULLOCK és munkatársai (1985) kézikönyv átdolgozott változata. Ebben már sokkal nagyobb hangsúlyt kapnak azok a komponensek is, amelyek kizárólag az emberi tevékenység eredményeként jelennek meg.

Ne ugorjunk ennyire előre azonban, mert meg jó néhány év kutatás előzi meg azt a folyamatot, melyeknek során ezek a definíciók kialakulnak. Az 1980-as évek végére, illetve a 90-es évek elejére tehető az az időszak, amikor jelentős számú kutató (többek között Matthew Canti (CANTI, 1995, 1997), Marie Agnes Courty (COURTY et al., 1989, 1994), Donald Davidson (DAVIDSON et al., 1992, DAVIDSON \& CARTER, 1998), Ewart FitzPatrick (FitzPATRICK, 1993), Charles French (FrENCH, 1991, 2003), Ann Gebhardt (GEBHARDT, 1995), Paul Goldberg (GOLDBERG, 1992; GoldBERG et al., 1994), Helen Lewis (LEWIS, 1998), Richard Macphail (MACPHAIL et al., 1990a, MACPHAIL \& GOLDBERG, 1995), Georges Stoops (STOOPS \& NIJS, 1986) csak néhány a legjelentősebbek közül) kifejezetten régészeti talajok/rétegek kutatásával kezd el foglalkozni. A kutatók többsége ekkor (néhányuk még a mai napig is) szinte kizárólag az egykori környezettel kapcsolatos kérdések megválaszolását helyezi a kutatás középpontjába. Mint az jól látható az egykori környezet változásaival, illetve a környezetváltozásért felelős emberi tevékenységekkel kapcsolatos kutatások több 10 éves múlttal és viszonylag nagy irodalmi háttéranyaggal rendelkeznek.

Az 1990-es évek elejétől, illetve közepétől azonban újabb, sokkal specifikusabb régészeti kérdések kerülnek előtérbe, így kifejlődik egy új irányzat a régészeti mikromorfológián belül. Ez az irányzat nem szakít teljesen a korábbi kutatással, hanem abból szervesen fejlődik ki. Az új irányzaton belül a hangsúly már az emberen, illetve az emberi tevékenységen, továbbá az épített környezeten van.

A nagyobb léptékü környezeti változásokat vizsgáló irányzat mellett tehát kialakul egy sokkal kisebb léptékü kutatás, ahol a természeti környezet helyett az ember és az emberi tevékenység, a mindennapi élet kap kiemelt szerepet. Ebben az esetben a mikromorfológia az ásatás mikroszkopikus szintre való kiterjesztését jelenti. Ez utóbbi irányzat, többek között elsőként Wendy Matthews (MATTHEWs et al., 1996, 1997a,b, 1998a,b, 2000) nevéhez füződik, később pedig igen meghatározó cikkek kerülnek ki Ian Simpson (SIMPSON \& BARRETT, 1996), Nicole Boivin (BoIVIN, 2000, 2001) Karen Milek (MILEK, 1999, 2003) és Ruth Shahack-Gross (SHAHACK-GROss et al., 2004) keze alól is.

Ezen a területen egyelőre még kis számú kutató dolgozik és a kutatások többnyire főleg a Közel-Keletre, Skandináviára, illetve néhány esetben Afrikára terjednek ki. Az általam vizsgált Százhalombatta-Földvár néven ismertté vált bronzkori lelöhely (KOVÁCS, 1969; POROSZLAI, 1992) képezi az első olyan közép-kelet-európai lelőhelyet, ahol az ilyen jellegü vizsgáltok is szerves részét képezik a hagyományos régészeti kutatásoknak.

Természetesen nem lehet éles határt húzni a fentiekben bemutatott kétféle irányzat között, hiszen egymásból szervesen fejlődtek ki, másrészt pedig a múlttal kapcsolatos kérdésekre megbízható választ csupán a két területen végzett kutatás együttes eredménye adhat. A lelőhelyeket nem lehet csupán önmagukban vizsgálni, kiragadva őket természetes környezetükböl. Hisz a környezeti tényezők nagymértékben meghatározzák az adott település kialakulását, fennmaradását és akár elhagyását is. Ugyanúgy, mint ahogy nincs település sem önmagában, hanem csupán valamilyen környezetbe ágyazva. 


\section{A vékonycsiszolatok jelentőssége}

A vékonycsiszolatok vizsgálata kiemelt jelentősséggel bír. A különféle komponensek eredeti formájukban vizsgálhatók, ezáltal feltárva nem csupán a komponensek egész sorát, hanem azok egymáshoz való viszonyát, ki- és esetleges átalakulásuk folyamatát.

A mikromorfológia módszere költség- és időigényes, ezért az átgondolt mintavételezés nagyon fontos. Mivel több száz minta feldolgozása rengeteg időt venne igénybe, a csiszolatok vizsgálata mellett fizikai és kémiai vizsgálatok széles skálája használatos [ $p H$ (Limbrey, 1975; STEIN, 1983; GRAVE \& KEALHOFER, 1999; KARKANAS et al., 2000; MATTHIESEN, 2004), foszfor vizsgálat (DAUNCEY, 1952; EIDT, 1973, 1977, 1984; CRADDOCK et al., 1985; CAVANAGH et al., 1988; LiPPI, 1988; MANZANILla \& BARBA, 1990; BALl \& Kelsay, 1992; LeONARDI et al., 1999; SCHLEZINGER \& HoweS, 2000; Wells et al., 2000; Parnell et al., 2001; Middleton, 2004; Sullivan \& KeAlHOFER, 2004; TERRY et al., 2004; FÜLEKY, 2005), izzitásos súlyvesztéses vizsgálatok (NELSON \& SOMMERS, 1996), mágneses vizsgálatok stb.], hogy térbeli kiterjedést nyerjenek a csiszolatban észlelt mikrojelenségek. Az utóbbi vizsgálatok azért is szükségesek, mert ellentétben a sokak által szubjektívnek ítélt mikromorfológiai leírásokkal, pontos számszerü adatokat szolgáltatnak, melyek alátámasztják a mikroszkópos megfigyeléseket.

A mikromorfológiai vizsgálatok során bebizonyosodott, hogy az antropogén rétegek esetében a rétegviszonyok nem annyira látványosak és nem minden esetben érzékelhetőek szabad szemmel, ellentétben a természetes talajokkal (ahol a fö szintek lényegesen eltérő tulajdonságokkal, szabad szemmel is könnyen észlelhető különbségekkel rendelkeznek.)

Az antropogén rétegek esetében számtalan esetben figyelhetök meg olyan finom rétegződések, amelyek az emberi szem által már nem érzékelhetők. Mivel ezek a finom rétegek csupán mikroszkóp alatt vizsgálhatók, terepen való mintázásuk nyilvánvalóan nem lehetséges. Természetesen így fizikai és kémiai vizsgálatuk (a fent említett hagyományos vizsgálatokon keresztül) is problematikus, a mikrorétegek esetleges keveredése miatt.

\section{Vékonycsiszolatok előállítása}

A mintavétel úgynevezett Kubiena dobozok (3. ábra) segítségével történik. Ezek a minta eredeti formában történő megőrzésében játszanak fontos szerepet, főként az antropogén rétegek mintázása során. A természetes talajok homogén szintjeinek mintázása nem feltétlenül teszi szükségessé a fémdoboz (müanyag változatok is használatosak (GOLDBERG, 2003)) alkalmazását. Az antropogén rétegek korábban említett fimon rétegeinek eredeti állapotban való megőrzése azonban több szempontból is indokolttá teszi a doboz használatát a mintavétel során. Mivel a régészeti mikromorfológia (akárcsak a régészet) egyik legfontosabb célja a rétegek egymáshoz való viszonyának a tisztázása, a rétegek eredeti állapotban történő megőrzése fontos kritérium. Továbbá az antropogén rétegek esetében a mintázandó anyag többnyire heterogén, ami a rétegek szétválásához vezethet, ezért a szilárdítás nélkülözhetetlen. Gondoljunk például egy tapasztott agyagpadlóra omlott szenült zsúptetőre, ahol a kemény agyag és a rajta fekvő törékeny szerves anyag együttes mintázása a két réteg azonnali szétválásához vezetne, ha nélkülöznénk a doboz használatát. 
A mintákat néhány héten keresztül szárítani szükséges, hogy a pórusokban található víz eltávozzon. Ha a pórusok vízzel telítettek az impregnáláshoz használt mügyanta nem képes teljesen átitatni a mintát, melynek következtében a rosszul előkészített minta alkalmatlan lesz a további feldolgozásra. A szárítás történhet szobahőmérsékleten, illetve szárítószekrényben a nedvességtartalomtól függően. Nagy mennyiségü víz estén ace-

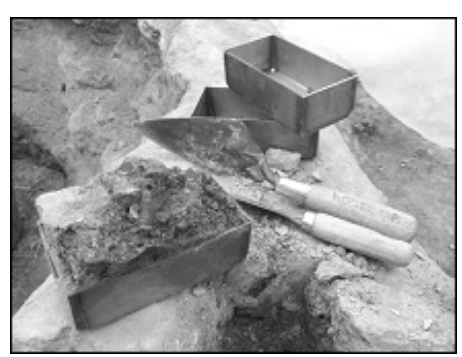

3. ábra

Kubiena doboz

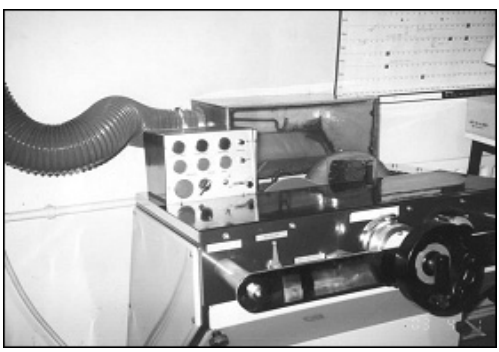

6. ábra

A minták polírozása

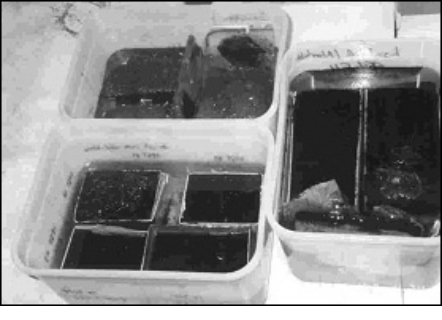

4. ábra

Impregnálás mügyantával

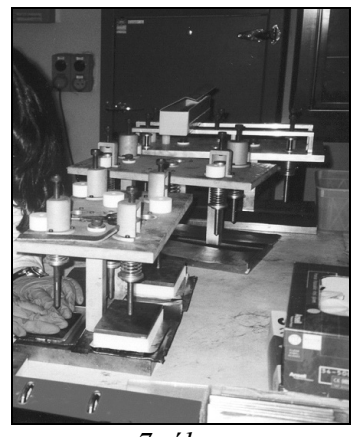

7. ábra

Préselés

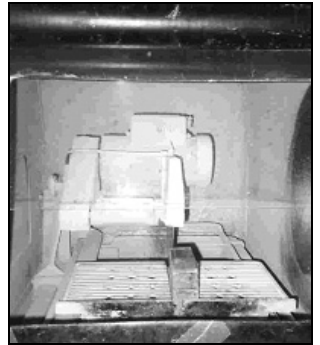

5. ábra

A minták vágása

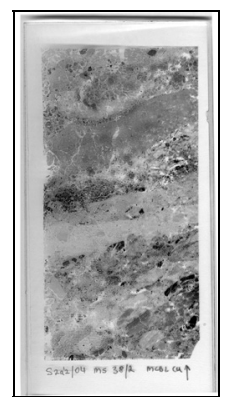

8. ábra

Vékonycsiszolat

(A 3. ábra felvétele a Százhalombatta-Földvár lelöhelyen, a 4-8. ábra felvételei a Cambridge-i Egyetem Régészettudományi Tanszékén, a McBurney Laboratóriumban készültek)

tonos vízcsere segítségével lehet a vízfelesleget eltávolítani. (Egyéb vízkivonási módszerek összefoglalását lásd: SzENDREI, 2000). A szárítás többnyire alacsony hőmérsékleten történik, szintén az érintetlen szerkezet megőrzése érdekében. Nagy agyagtartalmú minták estén a nagyfokú zsugorodás-tágulás miatt fokozott óvatosság szükséges. A szárítást követően a mintákat mügyantával itatjuk át (4. ábra), majd szilárdulás után vágógéppel (5. ábra) szeleteljük. A levágott kb. $5 \mathrm{~mm}$ vastagságú szeletet egy, az egyik oldalán polírozott üveglaphoz ragasztjuk, majd a szelet másik oldalát egy polírozó gép (6. ábra) segítségével egyenletesre csiszoljuk.

Ezt követően az üveglapról eltávolított minta csiszolt felét egy szintén csiszolt üveglaphoz ragasztjuk mügyanta segítségével és geológiai prés (7. ábra) alatt tartjuk 12-24 órán át, amíg a mügyanta teljesen meg nem szilárdul. Ezt követően további polírozás 
következik, míg egy 25-30 $\mu$ m vastagságot el nem érünk. A gépi csiszolást kézi csiszolás követi. Az antropogén rétegek esetében a szerves és a szervetlen, vagyis a jó és rossz megtartású anyagok nagyfokú keveredést mutathatnak adott mintán belül. Ennek következtében a keményebb, ellenállóbb komponensek (pl. kvarc szemcse) lassan kopnak, míg a finomabb anyagok (pl. szenült szerves anyag) az erőteljes polírozás következtében könnyen roncsolódhatnak. Ezért folyamatos ellenőrzés mellett kell az adott részeket megfelelő vastagságúra csiszolni, hogy később mikroszkóp alatt vizsgálhatóak legyenek. Ezt követően már csupán egy vékony fedőlemezzel zárjuk le az elkészült csiszolatot a későbbi sérülések és a minta kiszáradásának megakadályozása érdekében (MURPHY, 1986).

Az elkészült úgynevezett mamut vékonycsiszolatok (8. ábra) (méret kb. $8 \times 13 \mathrm{~cm}$ ) ezt követően mikroszkóp alatt vizsgálhatók.

\section{A mikromorfológia gyakorlati alkalmazása a régészetben}

A rövid történeti és gyakorlati áttekintés után térjünk rá konkrét példákra, hogy milyen módon is lehet a segítségünkre a mikromorfológia, amennyiben régészeti kérdésekre keressük a választ (1. táblázat).

Mint az korábban említésre került, kétféle irányzat létezik. Az első néhány példa azt szemlélteti, hogy a mikromorfológia milyen módon lehet a segítségünkre az egykori környezet rekonstruálásában, majd az azt követő példákon keresztül bepillantást nyerhetünk abba, hogy milyen kérdésekre kaphatunk választ, ha a kutatás középpontjában az emberi tevékenység áll.

\section{Természeti folyamatok - környezetrekonstrukció}

Az ilyen jellegü kutatások középpontjában a természetes folyamatok megjelenése és hatásai (árvíz, gleccser-, lejtőhatás, erózió, defláció, fagyhatás stb.), a korabeli környezetei viszonyok (vegetáció, élővilág, klíma), illetve a táj változásainak (folyómeder változása, feltöltődése, nyílt/zárt vegetáció ki- és átalakulása stb.) nyomon követése áll.

A természetes környezettel kapcsolatos kérdések természetesen kiterjednek az ember befolyásoló szerepének vizsgálatára is, hisz az ember megjelenése óta jelentős mértékü befolyást gyakorol környezetére.

Az eltemetett talajok vizsgálatán keresztül betekintést nyerhetünk azokba a folyamatokba, amelyek az adott talaj kialakítása során szerepet játszottak és közvetett információkat kaphatunk a korabeli környezeti feltételekkel kapcsolatban is.

A korabeli klímával kapcsolatban segítségünkre lehetnek a puhatestüek (Mollusca), melyek vékonycsiszolatban is tanulmányozhatók (9. ábra). Ezek az élőlények igen érzékenyen reagálnak bizonyos környezeti tényezők (hömérséklet, páratartalom, növényzet) meglétére illetve hiányára, tehát információval szolgálhatnak az egykori környezettel kapcsolatban.

A régészek számára a lelőhely megőrző képessége nagy jelentőséggel bír, hisz a talált leletek alapján vonják le következtetéseiket. A megőrző képesség nagymértékben függ azoktól a természeti tényezőktől és folyamatoktól, melyek a lelöhelyet érik. A mésztartalmú (pl. csont, kagyló, csiga) leletek elbomlásáért felelős lehet például a nagyfokú talajsavanyúság. A meszes talajok pedig kedveznek a földigiliszták elszaporodásá- 
1. táblázat

A régészeti mikromorfológia legfontosabb alkalmazási területei és azok forrásai

\begin{tabular}{|c|c|}
\hline Jelenség-régészeti probléma & Forrás \\
\hline & Természeti folyamatok \\
\hline Eltemetett talajok & FRENCH, 2003; MACPHAIL et al., 2003 \\
\hline Klímaváltozás & KARKANAS, 2002 \\
\hline $\begin{array}{l}\text { Talajképződés, talajfejlődés, } \\
\text { talajpusztulás }\end{array}$ & $\begin{array}{l}\text { BAKKER et al., 1996; DREES et al., 2003; FRENCH 2003; } \\
\text { GERASIMOVA, 2003; KHADEMI \& MERMUT, 2003; KOOISTRA } \\
\text { \& KoOISTRA, 2003; KOVDA et al., 2003; AYALA \& FRENCH, } \\
2005\end{array}$ \\
\hline Környezetrekonstrukció & $\begin{array}{l}\text { HOWARD \& MACKLIN, 1999; ANGELUCCI, 2003; FRENCH et } \\
\text { al., } 2003\end{array}$ \\
\hline Vegetáció rekonstrukció & GOLDBERG et al., 1994 \\
\hline $\begin{array}{l}\text { Talajok megórzö képessége } \\
\text {-bioturbáció }\end{array}$ & DAVIDSON, 2002; CANTI, 2003b; DAVIDSON et al., 2004 \\
\hline Tüzhasználat & $\begin{array}{l}\quad \text { Emberi tevékenység } \\
\text { COURTY et al., 1989; SCHIEGL et al., 1996, 2003; SIMPSON et } \\
\text { al., 2003; CANTI, 2003a }\end{array}$ \\
\hline Étkezés, feldolgozás & EXALTUS \& MIEDEMA, 1994; MATTHEWS et al., $1998 \mathrm{~b}$ \\
\hline Karbantartás, takarítás & $\begin{array}{l}\text { EXALTUS \& MIEDEMA, 1994; MATTHEWS et al., 1996, } \\
\text { 1997a,b; BOIVIN, 2000 }\end{array}$ \\
\hline Epítkezés-építōanyag & $\begin{array}{l}\text { STOOPS \& NIJ, 1986; COURTY et al., 1989; MATTHEWS et } \\
\text { al., 1996; BOIVIN \& FRENCH, 1998; MACPHAIL et al., 1998; } \\
\text { GEBHARDT \& LANGOHR, 1999 }\end{array}$ \\
\hline $\begin{array}{l}\text { Hulladékelhelyezés, } \\
\text {-hasznosítás }\end{array}$ & $\begin{array}{l}\text { SIMPSON \& BARRETT, 1996; SIMPSON et al., 1999; DAVIDSON } \\
\text { et al., } 2006\end{array}$ \\
\hline Járószintek-taposás & GÉ et al., 1993 ; MATTHEWS, 1995 ; MATTHEWS et al.,2000 \\
\hline Helyhasználat & $\begin{array}{l}\text { MACPHAIL et al., 1990a, 2004; EXALTUS \& MIEDEMA, 1994; } \\
\text { MATTHEWS et al., 1997b; MILEK, 1997, 1999; ALBERT et al., } \\
\text { 1999; TSATSKIN \& NADEL, 2003; SHAHACK-GROSS et al., } \\
2004\end{array}$ \\
\hline Állattartás & $\begin{array}{l}\text { COURTY et al., 1994; BOSCHIAN, 1997; CANTI, 1997, } 1998 \text {, } \\
\text { 1999, BoSCHIAN \& MONTAGNARI-KOKELJ, 2000; AKERET \& } \\
\text { RENTZEL, 2001; GUTTMANN et al., 2003; SHAHACK-GROSS et } \\
\text { al., 2003 }\end{array}$ \\
\hline Földmüvelés-földhasználat & $\begin{array}{l}\text { MACPHAIL et al., } 1990 \mathrm{~b} \text {; GEBHARDT, 1995; BRYANT \& } \\
\text { DAVIDSON, 1996; CARTER \& DAVIDSON, 1998; DAVIDSON \& } \\
\text { CARTER, 1998; MACPHAIL et al., 1998; ADDERLEY et al., } \\
2006\end{array}$ \\
\hline
\end{tabular}

nak. Utóbbi azonban a nagyfokú bioturbáció miatt (10. ábra) kedvezőtlen lehet a leletek eredeti helyének megőrzése szempontjából. Hasonlóképp befolyásolhatják a leletek eredeti helyükről való elmozdulását a korábban már említett természeti jelenségek (árvíz, erózió stb.). Ezek a jelenségek is jól vizsgálhatóak a mikroszkóp alatt. 


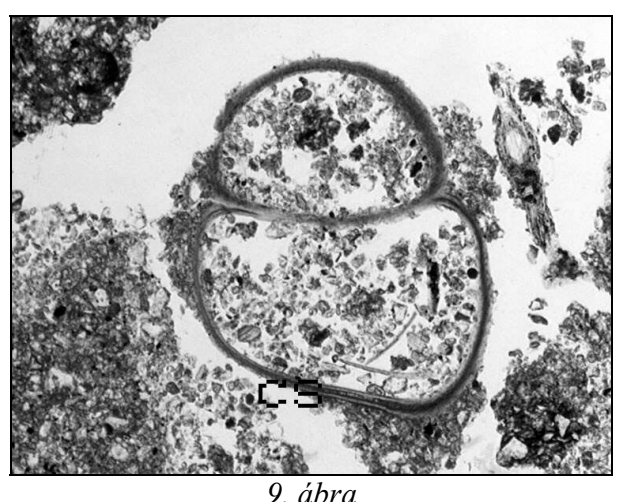

Csiga mészváza

(Lelőhely: Százhalombatta-Földvár

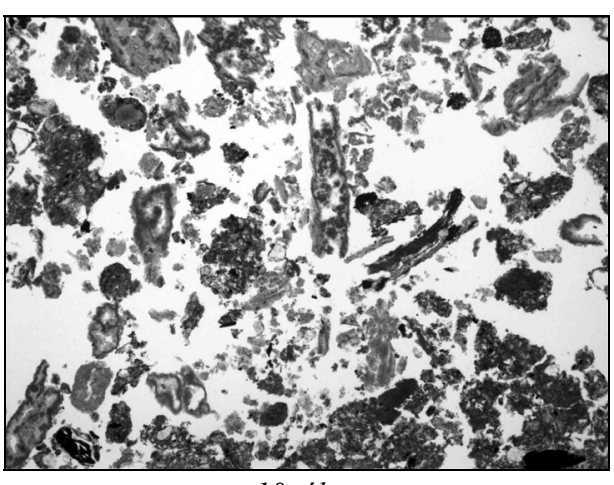

10. ábra

Bioturbáció

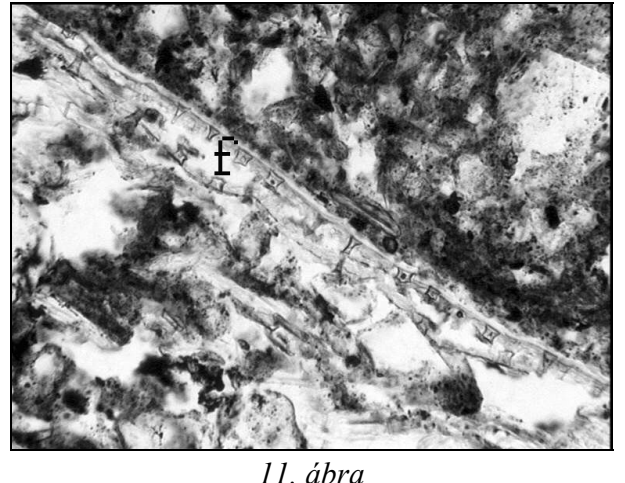

Fitolit (f) (Nagyítás 100×)

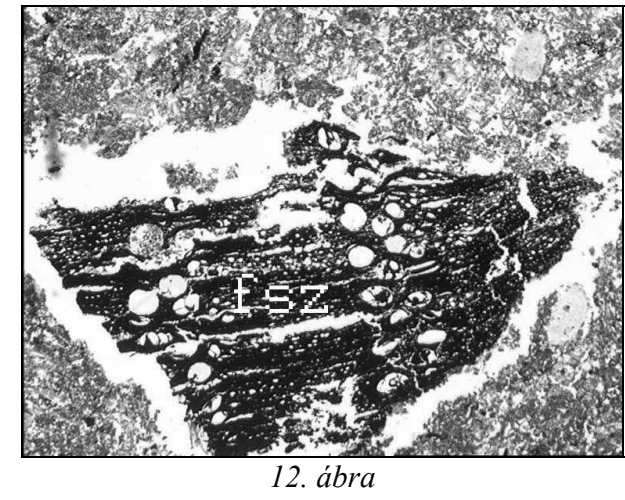

Faszén (fsz) (mikrofotó mérete: $6 \mathrm{~mm}$ )

(Lelőhely: Százhalombatta-Földvár)

A korabeli vegetáció rekonstruálásában a fitolit- (11. ábra), a faszén- (12. ábra) és a pollenmaradványok lehetnek segítségünkre. A pollenek és a fitolitok mikroszkopikus méretüknek köszönhetően a lelőhelyen hagyományos ásatási módszerekkel nem tárhatóak fel. A faszén-, a fitolit-, illetve a pollenvizsgálatok ugyan már önálló tudományokká nőtték ki magukat, azonban az alkalmazott kivonási módszereknek köszönhetően ezek az anyagok eredeti közegükből kiragadva kerülnek megvizsgálásra. Mivel ezek a térbeli kiterjedéssel bíró anyagok olyan fajtabélyegeket is tartalmazhatnak, amelyeket a csiszolatok kétdimenziós módszerével nem tudunk megfigyelni, a különféle technikák együttes alkalmazására kell törekednünk, annak érdekében, hogy a lehető legapróbb információk is napvilágra kerüljenek.

\section{Emberi tevékenység, mindennapi élet}

Abban az esetben, ha az emberi tevékenység során felhalmozódott vagy lerakódott anyagot vizsgáljuk, olyan anyagokkal is találkozni fogunk, amik a természetes talajokban nem fordulnak elö. Ilyenek például, a kerámiatöredékek (13. ábra), szenült növény- 


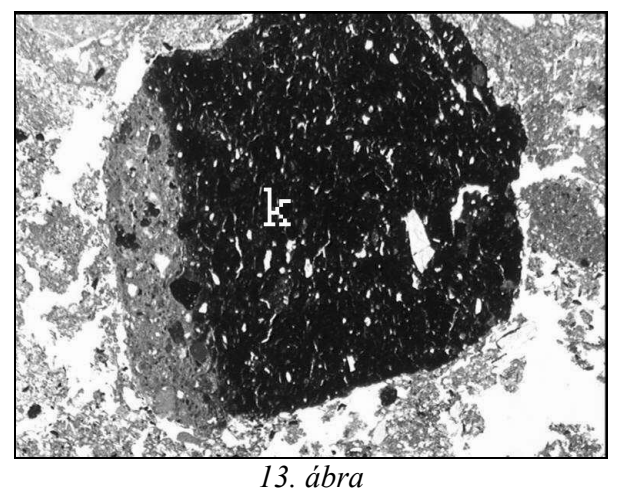

Kerámiatöredék (mikrofotó mérete: 6 mm)

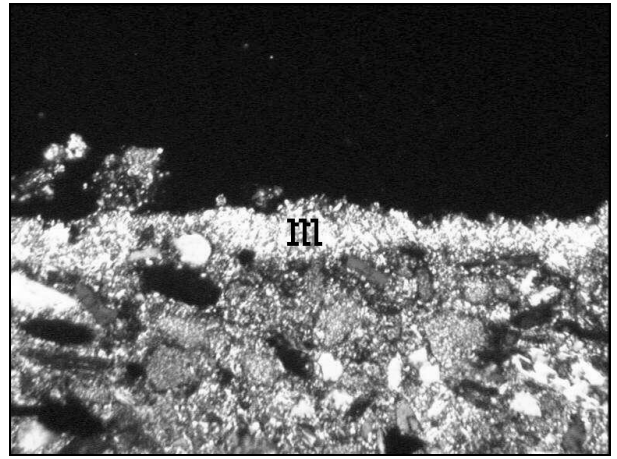

15. ábra

Meszelés (Nagyítás 100×)

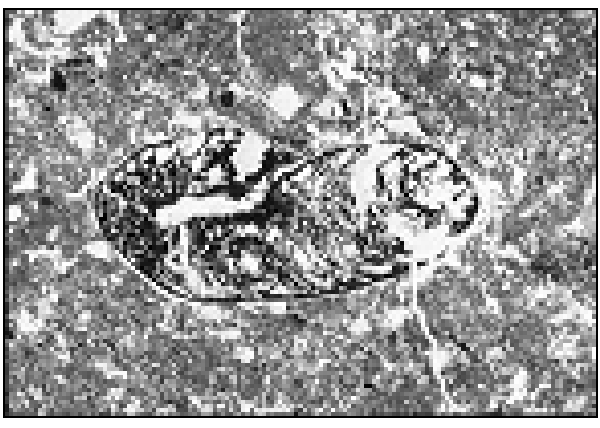

14. ábra

Szénült gabona (mikrofotó mérete: $6 \mathrm{~mm}$ )

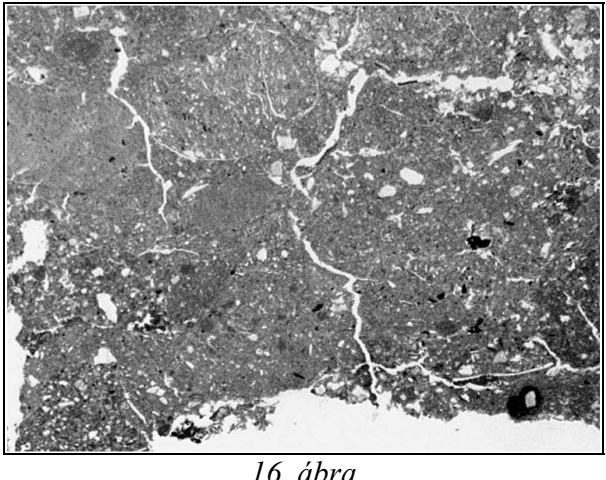

Padló (Nagyítás 6×)

(Lelöhely: Százhalombatta-Földvár)

maradványok (14. ábra), építési anyagok (mész (15. ábra), padlókészítésre használt agyag (16. ábra), patics (17. ábra)), gyékénylenyomat (18. ábra) vagy az istállózó állattartás következtében megjelenő trágyaakkumuláció is. Csont (19. ábra), égetett csont (20. ábra), faszén ugyan előfordulhat a természetes talajokban is (pl. erdőtűz után belekeveredik a talajba) (COURTY et al., 1989). Azonban míg ezek az összetevők csupán egy természetes folyamat végtermékeként jelennek meg a természetben, addig ugyanezek a komponensek régészeti környezetben meghatározhatnak egy bizonyos tevékenységet (pl. ételkészítés, étkezés).

Bizonyos esetekben kizárólag hagyományos régészeti technikákat alkalmazva nem lehet meghatározni azokat a tevékenységeket, amelyek egy adott helységhez vagy felülethez tartoznak. Ez föleg azokban a helyzetekben a legnehezebb, amikor a lelöhely békés elhagyásával fejeződött be az adott lelőhely élete.

Ebben az esetben ugyanis a tárgyak többsége (föképp az értékesebb, nehezen pótolható holmik) elszállításra kerülnek és csupán az értéktelen, vagy könnyen pótolható tárgyak maradnak meg a régészek számára (CAMERON \& TOMKA, 1993). Éppen ezért kevés és nem reprezentatív adatot szolgáltatnak a korabeli mindennapi tevékenységekkel kapcsolatban. A mikroszkopikus méretủ maradványok eredeti helyükröl való el- 


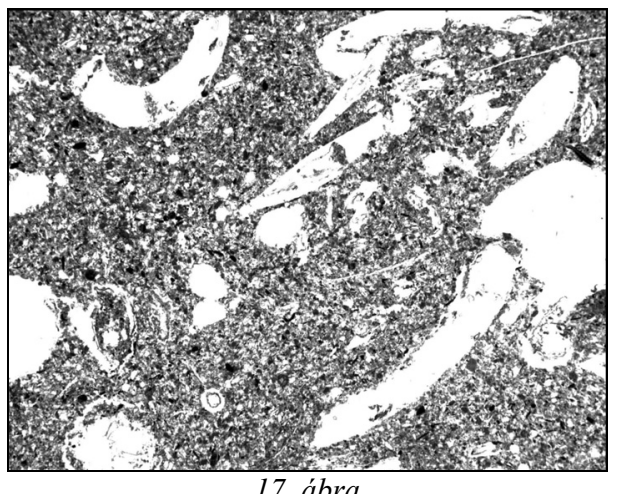

Patics (mikrofotó mérete: $6 \mathrm{~mm}$ )

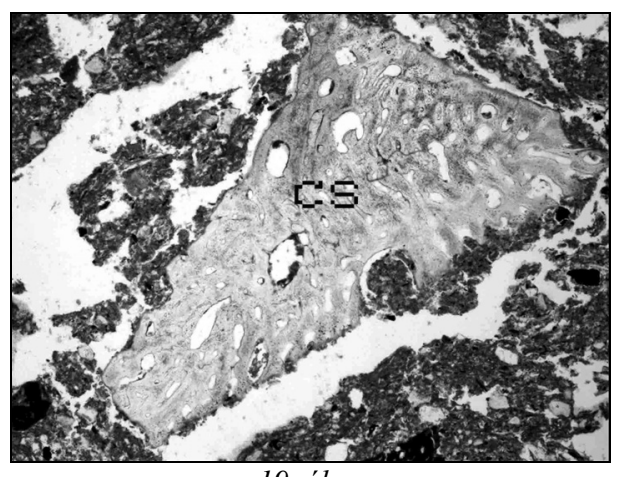

19. ábra

Csont (cs) (mikrofotó mérete: $6 \mathrm{~mm}$ )

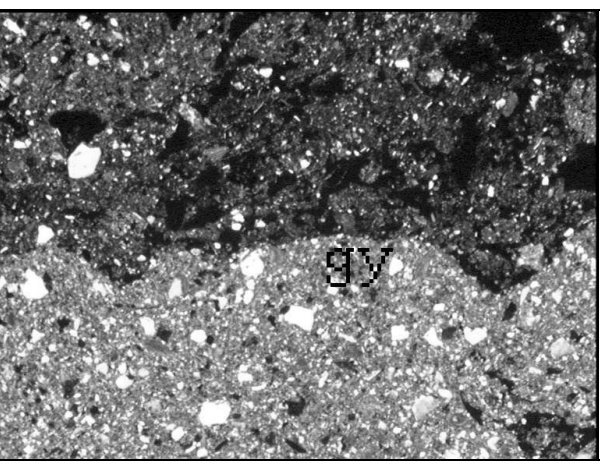

18. ábra

Gyékény lenyomat (gy) (Nagyítás: 5,8×)

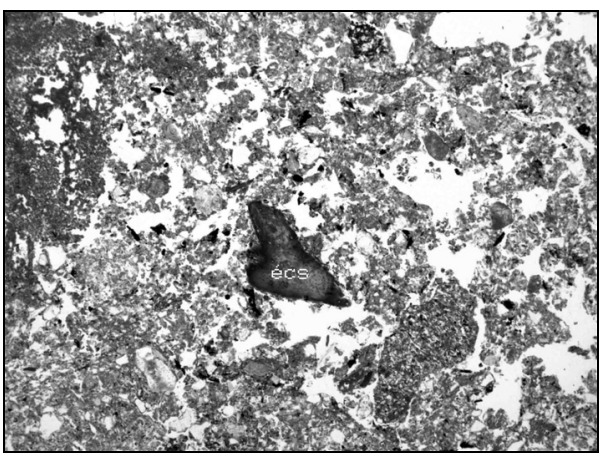

20. ábra

Égett csont (écs) (középen)

(mikrofotó mérete: $6 \mathrm{~mm}$ )

(Lelöhely: Százhalombatta-Földvár)

mozdulásának kisebb a valószínüsége (SCHIFFER, 1983). Ez természetesen nem csupán az elhagyott telepek esetében szolgáltathat bizonyítékot bizonyos tevékenységek meglétére és térbeli eloszlására, hanem tisztán tartott felültek esetében is, ahol szintén korlátozott mennyiségben vannak jelen a makroszkopikus mérettartományba tartozó leletek.

A mikroszkopikus elemek továbbá eredeti környezetükben kerülnek tanulmányozásra, így lerakódásuk, illetve mindazok a folyamatok, melyek a leleteket a lerakódást követően érték, hatékonyan vizsgálhatóak.

\section{Következtetés}

A régészeti mikromorfológia, talajfizika és talajkémia széleskörü alkalmazásának köszönhetően, kortól, lelőhelytől függetlenül nagy hatékonysággal alkalmazható. Az alkalmazott vizsgálatok sorát ezzel a módszerrel kiegészítve, olyan információk nyerhetőek, melyek más technikák segítségével nem. A felhasznált irodalmak természetesen 
csupán töredék részét képezik annak a hatalmas információforrásnak, mely a kutatók számára rendelkezésre áll. A legalapvetőbb és néhány esetben a legújabb eredmények megemlítése csupán segítséget kíván nyújtani mindazok számára, akik a régészeti mikromorfológia rejtélyeiben mélyebben el kívánnak merülni.

\section{Irodalom}

AdDerley, W. P., Simpson, I. A. \& Davidson, D. A., 2006. Historic landscape management: a validation of quantitative soil thin-section analyses. Journal of Archaeological Science. 33. 320-334.

AKERET, Ö. \& RENTZEL, P., 2001. Micromorphology and plant macrofossil analysis of cattle dung from the neolithic lake shore settlement of Arbon Bleiche. 3. Geoarchaeology: An International Journal. 16. 687-700.

Albert, R. M. et al., 1999. Mode of occupation of Tabun Cave, Mt Carmel, Israel during the Mousterian period: A study of the sediments and phytoliths. Journal of Archaeological Science. 26. 1249-1260.

AngeluCCI, D. E., 2003. Geoarchaeology and micromorphology of Abric de la Cativera (Catalonia, Spain). Catena. 54. 573-601.

AyAla, G. \& French, C. A. I., 2005. Erosion modeling of past land-use practices in the Fiume di Sotto di Troina River Valley, North-Central Sicily. Geoarchaeology: An International Journal. 20. 149-167.

BAKKer, L., Lowe, D. J. \& Jongmans, A. G., 1996. A micromorphological study of pedogenic processes in an evolutionary soil sequence formed on Late Quaternary rhyolitic tephra deposits, North Island, New Zealand. Quarternary International. 34-36. 249-261.

Ball, J. W. \& Kelsay, R. G., 1992. Prehistoric Intrasettlement Land Use and Residual Soil Phosphate Levels in the Upper Belize Valley, Central America. University of Alabama Press. Tuscaloosa.

Borvin, N., 2000. Life rhythms and floor sequences: excavating time in Rural Rajasthan and Neolithic Çatalhöyük. World Archaeology. 31. 367-388.

Borvin, N., 2001. Archaeological Science as Anthropology: Space, Time and Materiality in Rural India and the Ancient Past. University of Cambridge, Doktori Disszertáció.

BoIVIN, N. L. \& FrENCH, C. A. I., 1998. New questions and answers in the micromorphology of the occupation deposits at the Souks Site, Beirut. Berytus. 43. 181-210.

Boschian, G., 1997. Sedimentology and soil micromorphology of the Late Pleistocene and Early Holocene deposits of Grotta dell'Edera (Trieste Karst, NE Italy). Geoarchaeology: An International Journal. 12. 227-249.

Boschian, G. \& Montagnari-KokelJ, E., 2000. Prehistoric shepherds and caves in the Trieste Karst (Northeastern Italy). Geoarchaeology: An International Journal. 15. 331-371.

BREwer, R., 1964. Fabric and Mineral Analysis of Soils. Wiley and Sons. New York.

BRYANT, R. G. \& DAVIDSON, D. A., 1996. The use of image analysis in the micromorphological study of old cultivated soils: an evaluation based on soils from the Island of Papa Stour, Shetland. Journal of Archaeological Science. 23. 811-822.

Bullock, P. et al., 1985. Handbook for Soil Thin Section Description. Waine Research Publications. Wolverhampton.

CAmeron, C. M. \& TomkA, S. A., 1993. Abandonment of Settlements and Regions. Ethnoarchaeological and Archaeological Approaches. Cambridge University Press. Cambridge.

CANTI, M. G., 1995. A mixed-method approach to geoarchaeological analysis. In: Archaeological Sediments and Soils: Analysis, Interpretation and Management. (Eds.: BARHAM, A. \& MACPHAIL, R. I.) 183-190. Architype Books. London. 
CANTI, M. G., 1997. An investigation of microscopic calcareous spherulites from herbivore dungs. Journal of Archaeological Science. 24. 219-231.

CANTI, M. G., 1998. The micromorphological identification of faecal spherulites from archaeological and modern materials. Journal of Archaeological Science. 25. 435-444.

CANTI, M. G., 1999. The production and preservation of faecal spherulites: Animals, environment and taphonomy. Journal of Archaeological Science. 26. 251-258.

CANTI, M. G., 2003a. Aspects of the chemical and microscopic characteristics of plant ashes found in archaeological soils. Catena. 54. 339-361.

CANTI, M. G., 2003b. Earthworm activity and archaeological stratigraphy: A review of products and processes. Journal of Archaeological Science. 30. 135-148.

CARTER, S. \& DAVIDSON, D., 1998. An evaluation of the contribution of soil micromorphology to the study of ancient arable agriculture. Geoarchaeology. 13. 535-547.

CAvanagh, W. G., HiRst, S. \& LitTon, C. D., 1988. Soil phosphate, site boundaries, and change point analysis. Journal of Field Archaeology. 15. 67-83.

CoRnwall, I. W., 1958. Soils for the Archaeologists. Phoenix House Ltd. London.

Courty, M. A., Goldberg, P. \& Macphail, R. I., 1989. Soils and Micromorphology in Archaeology. Cambridge University Press. Cambridge.

Courty, M. A., Goldberg, P. \& Macphail, R. I., 1994. Ancient people - lifestyles and cultural patterns. In: Trans. $15^{\text {th }}$ World Congress of Soil Science. Micromorphological Indicators of Anthropogenic Affects on Soils. (Eds.: Wilding, L. \& OleshKo, K.) 6a. 250-269. Acapulco, Mexico.

CRADDOCK, P. T. et al., 1985. The application of phosphate analysis to the location and interpretation of archaeological sites. Archaeological Journal. 142. 361-376.

DAUNCEY, K. D. M., 1952. Phosphate content of soils on archaeological sites. Advancement of Science. 9. 33-37.

DAVIDSON, D. A., 2002. Bioturbation in old arable soils: quantitative evidence from soil micromorphology. Journal of Archaeological Science. 29. 1247-1253.

DAVIDSON, D. A. \& CARTER, S. P., 1998. Micromorphological evidence of past agricultural practices in cultivated soils: The impact of a traditional agricultural system on soils in Papa Stour, Shetland. Journal of Archaeological Science. 25. 827-838.

DAvidson, D. A., CARTER, S. P. \& Quine, T. A., 1992. An evaluation of micromorphology as an aid to archaeological interpretation. Geoarchaeology: An International Journal. 7. 55-65.

DAVIDSON, D. A. et al., 2004. Micromorphological assessment of the effect of liming on faunal excrement in an upland grassland soil. Applied Soil Ecology. 26. 169-177.

DAVIDSON, D. A. et al., 2006. The legacy of past urban waste disposal on local soils. Journal of Archaeological Science. 33. 745-892.

DREES, L. R. et al., 2003. Steepland resources: characteristics, stability and micromorphology. Catena. 54. 619-636.

EIDT, R. C., 1973. A rapid chemical field test for archaeological site surveying. American Antiquity. 38. 206-210.

EIDT, R. C., 1977. Detection and examination of Anthrosols by phosphate analysis. Science. 197. $1327-1333$.

EIDT, R. C., 1984. Advances in Abandoned Settlement Analysis: Application to Prehistoric Anthrosols in Colombia. University of Wisconsin, Center for Latin American Studies, Milwaukee.

Exaltus, R. P. \& Miedema, R., 1994. A micromorphological study of four Neolithic sites in the Dutch coastal provinces. Journal of Archaeological Science. 21. 289-301.

FitzPATRick, E. A., 1993. Soil Microscopy and Micromorphology. Wiley. Chichester.

French, C. A. I., 1991. Fengate 1989: The Soil Micromorphological Report. Fengate Archaeological Trust. Kézirat.

FrenCH, C. A. I., 2003. Geoarchaeology in Action: Studies in Soil Micromorphology and Landscape Evolution. Routledge. London. 
FrenCH, C. A. I. et al., 2003. Archaeological and Palaeo-environmental Investigations of the Upper Allen Valley, Cranborne Chase, Dorset (1998-2000): A New Model of Earlier Holocene Landscape Development. Proceedings of the Prehistoric Society. 69. 201-234.

FÜLEKY, GY., 2005. Soils of the Bronze Age tell in Százhalombatta. In: SAX, Százhalombatta Archaeological Expedition, Annual Report 2-Field Season 2000-2003. (Eds.: PorosZlaI, I. \& Vicze, M.) 89-110. "Matrica" Múzeum. Százhalombatta.

GEBHARDT, A., 1995. Soil micromorphological data from traditional and experimental agriculture. In: Archaeological Sediments and Soils: Analysis, Interpretation and Management. (Eds.: BARHAM, A. \& MACPHAIL, R. I.)25-39. Architype Books. London.

GEBHARDT, A. \& LANGOHR, R.. 1999. Micromorphological study of construction materials and living floors in the medieval Motte of Werken, (West Flanders, Belgium). Geoarchaeology: An International Journal. 14. 595-620.

GÉ, T. et al., 1993. Sedimentary formation processes of occupation surfaces. In: Formation Processes in Archaeological Context. Monographs in World Archaeology. (Eds.: GolDBERG, P., Nash, D. T. \& Petraglia, M. D.) 17. 149-163.

Gerasimova, M., 2003. Higher levels of description-approaches to the micromorphological characterisation of Russian soils. Catena. 54. 319-337.

GolDBERG, P., 1992. Micromorphology, soils and archaeological sites. In: Soils in Archaeology. (Ed.: Holliday, V. T.) 145-167. Smithsonian Institution Press. Washington-London.

GoldBerg, P., 2003. Short contribution: Strategies and techniques in collecting micromorphology samples. Geoarchaeology: An International Journal. 18. 571-578.

Goldberg, P., LeV-YAdUN, S. \& BAR-YOSEF, O., 1994. Petrographic thin sections of archaeological sediments: A new method for paleobotanical studies. Geoarchaeology: An International Journal. 9. 243-257.

Grave, P. \& KeAlHOFER, L., 1999. Assessing bioturbation in archaeological sediments using soil morphology and phytolith analysis. Journal of Archaeological Science. 26. 1239-1248.

GutTMAnN, E. B. A., Simpson, I. A. \& Dockrill, S. J., 2003. Joined-up archaeology at Old Scatness, Shetland: Thin section analysis of the site and hinterland. Environmental Archaeology. 8. 17-31.

HowARD, A. J. \& MACKLIN, M. G., 1999. A generic geomorphological approach to archaeological interpretation and prospection in British river valleys: a guide for archaeologists investigating Holocene landscape. Antiquity. 73. 527-541.

K-BERZSÉNYI B. \& KovÁCs G., 2004. Az ember környezetre gyakorolt hatása SzázhalombattaFöldvár Bronzkori lelöhely területén. In: A táj változásai a Kárpát-medencében. Víz a tájban. (Szerk.: FÜleKY Gy.) 399-401. Környezetkímélő Agrokémiáért Alapítvány. Gödöllő.

KARKANAS, P., 2002. Micromorphological studies of Greek prehistoric sites: new insights in the interpretation of the archaeological record. Geoarchaeology: An International Journal. 17. $237-259$.

KARKANAS, P. et al., 2000. Diagenesis in prehistoric caves: the use of minerals that form in situ to assess the completeness of the archaeological record. Journal of Archaeological Science. 27. 915-929.

Khademi, H. \& Mermut, A. R., 2003. Micromorphology and classification of Argids and associated Gypsiferous Aridisols from Central Iran. Catena. 54. 439-455.

KoOISTRA, M. J. \& KoOISTRA, L. I., 2003. Integrated research in archaeology using soil micromorphology and palynology. Catena. 54. 603-617.

KovÁCS T., 1969. A Százhalombattai Bronzkori Telep. ArchÉrt. 96. 161-169.

Kovda, I. V., Wilding, L. P. \& Drees, L. R., 2003. Micromorphology, submicroscopy and microprobe study of carbonate pedofeatures in a Vertisol Gilgai soil complex, South Russia. Catena. 54. 457-476.

KuBIENA, W. L., 1938. Micropedology. Collegiate Press. Ames, Iowa. 
LeOnardi, G., Miglavacca, M. \& NARDi, S., 1999. Soil phosphorus analysis as an integrative tool for recognizing buried ancient ploughsoils. Journal of Archaeological Science. 26. 343 352.

LEwIS, H. A., 1998. The Characterization and Interpretation of Ancient Tillage Practises Through Soil Micromorphology: a Methodological Study. University of Cambridge, Doktori Disszertáció.

Limbrey, S., 1975. Soil Science in Archaeology. Academic Press. London.

LIPPI, R. D., 1988. Paleotopography and phosphate analysis of a buried jungle site in Ecuador. Journal of Field Archaeology. 15. 85-97.

MACPHAIL, R. I. \& GOLDBERG, P., 1995. Recent advances in micromorphological interpretations of soils and sediments from archaeological sites. In: Archaeological Sediments and Soils: Analysis, Interpretation and Management. (Eds.: BARHAM, A. \& MACPHAIL, R. I.) 1-24. Architype Books. London.

Macphail, R. I., Courty, M. A. \& GoldberG, P., 1990a. Soil micromorphology in archaeology. Endeavour. New Series. 14. 163-171.

Macphail, R., Courty, M. A. \& Gebhardt, A., 1990b. Soil micromorphological evidence of early agriculture in North West Europe. World Archaeology. 22. 53-69.

MACPHAIL, R. I. et al., 1998. Micromorphological interpretation of a "turf-filled" funerary shaft at St. Albans, United Kingdom. Geoarchaeology: An International Journal. 13. 617-644.

MACPHAIL, R. I. et al., 2003. The experimental earthwork at Wareham, Dorset after 33 years: changes to the buried LHF and Ah horizons. Journal of Archaeological Science. 30. 77-93.

MACPHAIL, R. I. et al., 2004. Archaeological soil and pollen analysis of experimental floor eeposits: with special reference to Butser Ancient Farm, Hampshire, UK. Journal of Archaeological Science. 31. 175-191.

Manzanilla, L. \& Barba, L., 1990. The study of activities in classic households. Ancient Mesoamerica. 1. 41-49.

MATtHEWs, W., 1995. Micromorphological characterisation and interpretation of occupation deposits and microstratigraphic sequences at Abu Salabikh, Iraq. In: Archaeological Sediments and Soils: Analysis, Interpretation and Management. (Eds.: BARHAM, A. J. \& MACPHAIL, R. I.) 41-76. Archetype Books. London.

Matthews, W. et al., 1996. Multiple surfaces: the micromorphology. In: On the Surface: Çatalhöyük 1993-95. (Ed.: HoDDER, I.) 301-342. British Institute of Archaeology at Ankara, McDonald Institute, Cambridge.

MATTHEWS, W. et al., 1997a. Activities inside the temple: the evidence of microstratigraphy. In: The Dilmun Temple at Saar. (Eds.: Crawford, H. E. W., Killick, R. \& Moon, J.) 31-46. Kegan Paul International. London.

MATTHEWS, W. et al., 1997b. Microstratigraphic traces of site formation processes and human activities. World Archaeology. 29. 281-308.

MATTHEWS, W. et al., 1998a. Microstratigraphy and micromorphology of depositional sequences. In: Excavations at Tell Brak. (Eds.: OATES, D., OATES, J. \& MCDOnALD, H.) 135-154. British School of Archaeology Iraq. McDonald Institute, Cambridge.

MAtTHews, W. et al., 1998b. Investigation of Archaeological Plant Remains by Micromorphology, Microcontextual Identification, Quantification and Taphonomy. Department of Archaeology, University of Cambridge. Kézirat.

MATtHEWS, W. et al., 2000. Microstratigraphic analysis of depositional sequences in areas FS and SS. In: Excavations at Tell Brak. (Eds.: OAtes, D., OATES, J. \& McDonald, H.) 353367. British School of Archaeology in Iraq. McDonald Institute, Cambridge.

MatthiESEN, H., 2004. In situ measurement of soil pH. Journal of Archaeological Science. 31. $1373-1381$.

MidDLETON, W. D., 2004. Identifying chemical activity residues on prehistoric house floors: A methodology and rationale for multi-elemental characterization of a mild acid extract of anthropogenic sediments. Archaeometry. 46. 47-65. 
MiLEK, K., 1997. Micromorphology and the Medieval Urban Environment: Examples from Ely and Peterborough, Cambridgeshire, England. Environment and Subsistence in Medieval Europe - Papers of the "Medieval Europe Brugge 1997" Conference. 9

MileK, K., 1999. Soil micromorphology. In: Rushen Abbey, Ballasalla, Isle of Man. First Archaeological Report. (Ed.: DAVEY, P. J.) 77-93. Centre Fox Manx Studies, University of Liverpool.

MiLEK, K., 2003. Sediments and sagas: Illuminating spatial order in Viking Age Scandinavian houses. In: $2^{\text {nd }}$ International Conference on Soils and Archaeology. (Ed.: BosCHIAN, G.) 6770. Felici Editore. Pisa, Italy.

MurPhy, C. P., 1986. Thin Section Preparation of Soils and Sediments. A. B. Academic. Berkhamsted.

Nelson, D. W. \& SOMmers, L. E., 1996. Total carbon, organic carbon and organic matter. In: Methods of Soil Analysis Part 3: Chemical Methods. (Ed.: SPARKS, D. L.) 961-1010. Soil Science Society of America. Madison.

Parnell, J. J., Terry, R. E. \& Golden, C., 2001. Using in-field phosphate testing to rapidly identify middens at Piedras Negras, Guatemala. Geoarchaeology: An International Journal. 16. $855-873$.

PIPERnO, D. R., 1988. Phytolith Analysis: An Archaeological and Geological Perspective. Academic Press. London.

PoroszlaI, I., 1992. Százhalombatta-Földvár. In: Bronzezeit in Ungarn, Forschungen in Tellsiedlungen an Donau und Theiss. (Ed.: BóNA, I.) 153-155. Frankfurt am Main.

Schiegl, S. et al., 1996. Ash deposits in Hayonim and Kebara Caves, Israel: Macroscopic, microscopic and mineralogical observations, and their archaeological implications. Journal of Archaeological Science. 23. 763-781.

SCHIEGL, S. et al., 2003. Paleolithic burnt bone horizons from the Swabian Jura: Distinguishing between in situ fireplaces and dumping areas. Geoarchaeology: An International Journal. 18. $541-565$.

SCHIFFER, M. B., 1983. Toward the identification of formation processes. American Antiquity. 48. $675-706$.

SCHLEZINGER, D. R. \& Howes, B. L, 2000. Organic phosphorus and elemental ratios as indicators of prehistoric human occupation. Journal of Archaeological Science. 27. 479-492.

SHAHACK-GRoss, R., MARSHALl, F. \& WeINER, S., 2003. Geo-ethnoarchaeology of pastoral sites: The identification of livestock enclosures in abandoned Maasai settlements. Journal of Archaeological Science. 30. 439-459.

SHAHACK-Gross, R. et al., 2004. Reconstruction of spatial organization in abandoned Maasai settlements: Implications for site structure in the Pastoral Neolithic of East Africa. Journal of Archaeological Science. 31. 1395-1411.

SIMPSON, I. A. \& BARRETT, J. H., 1996. Interpretation of Midden formation processes at Robert's Haven, Caithness, Scotland using thin section micromorphology. Journal of Archaeological Science. 23. 543-556.

Simpson, I. A., MileK, K. B. \& Gudmundsson, G., 1999. A reinterpretation of the Great Pit at Hofstadir, Iceland using sediment thin section micromorphology. Geoarchaeology: An International Journal. 14. 511-530.

SiMPSON, I. A. et al., 2003. Fuel resource utilisation in landscapes of settlement. Journal of Archaeological Science. 30. 1401-1420.

SteIN, J. K., 1983. Earthworm activity: A source of potential disturbance of archaeological sediments. American Antiquity. 48. 277-289.

Stoops, G., 2003. Guidelines for Analysis and Description of Soil Regolith and Thin Section. Soil Science Society of America Inc., Madison, Wisconsin, USA

Stoops, G. \& Niss, R., 1986. Micromorphological characteristics of some tell materials from Mesopotamia. Pedologie. 36. (3) 329-336. 
Sullivan, K. A. \& KeAlhofer, L., 2004. Identifying activity areas in archaeological soils from a Colonial Virginia house lot using phytolith analysis and soil chemistry. Journal of Archaeological Science. 31. 1659-1673.

SzENDREI G., 2000. Talaj-mikromorfológia. ELTE Eötvös Kiadó. Budapest.

TERRY, R. E. et al., 2004. The story in the floors: Chemical signatures of ancient and modern Maya activities at Aguateca, Guatemala. Journal of Archaeological Science. 31. 1237-1250.

TSATSKIN, A. \& NADEL, D., 2003. Formation processes at the Ohalo II submerged prehistoric campsite, Israel, inferred from soil micromorphology and magnetic susceptibility studies. Geoarchaeology: An International Journal. 18. 409-432.

VICZE, M., 2005. Excavation methods and some preliminary results of the SAX project. In: SAX, Százhalombatta Archaeological Expedition, Annual Report 2-Field Season 2000-2003. (Eds.: Poroszlai, I. \& Vicze, M.) 65-80. "Matrica" Múzeum. Százhalombatta.

WeLls, E. C. et al., 2000. Chemical analyses of ancient Anthrosols in residential areas at Piedras Negras, Guatemala. Journal of Archaeological Science. 27. 449-462.

Érkezett: 2006. május 25.

KOVÁCS GABRIELLA

Cambridge-i Egyetem, Régészeti Tanszék, McBurney Laboratórium, Cambridge, UK

Postai cím: KOVÁCS GABRIELLA, „Matrica” Múzeum, 2440 Százhalombatta, Gesztenyés u. 1-3.E-mail: antropologus@yahoo.com 